\title{
TINJAUAN KECELAKAAN LALU LINTAS ANTAR WILAYAH PADA JALAN TRANS PROVINSI SULAWESI SELATAN
}

\author{
Amiruddin Akbar Fisu ${ }^{1)}$ \\ ${ }^{1)}$ Dosen Program Studi Teknik Sipil, Universitas Andi Djemma, Palopo \\ 1) amiruddinakbarfisu07@gmail.com
}

\begin{abstract}
Abstrak
Kecelakaan lalu lintas dijalan raya merupakan penyumbang angka kematian terbesar di dunia. World Health Organization (WHO) mencatat hampir 3.400 orang meninggal di jalan dunia setiap hari. Puluhan juta orang terluka setiap tahun. Anak, pejalan kaki, pengendara sepeda dan orang tua paling rentan dari pengguna jalan. Secara umum Kepolisian Republik Indonesia mencatat 98.419 kecelakaan pada tahun 2017. Pelaporan oleh polisi dan keakuratan laporan polisi akan memastikan penentuan pengelompokan penyebab terjadinya kecelakaan dan dengan demikian akan memungkinkan penyusunan daftar penyebab sebagai sesuatu yang berpengaruh pada terjadinya kecelakaan. Hal ini dilakukan dengan menyusun jumlah data kecelakaan pada lokasi tertentu dan jenis cedera kecelakaan atau sistem pembobotan (Asian Development Bank, 1998: 42). Untuk menganalisis setiap permasalahan yang ada, langkah pertama adalah membawa pengetahuan ke data yang ada. Penemuan pengetahuan dimulai pada lingkungan tingkat dan pengumpulan data dari sumber data. Mencermati data, tujuan dapat disesuaikan, dan berdasarkan tujuan data target dapat dipilih. Sulawesi selatan sebagai salah satu provinsi dengan jumlah pergerakan antar wilayah yang cukup padat. Dengan intensitas pergerakan yang sibuk, tidak sedikit kecelakaan lalu lintas yang terjadi. Tulisan ini menganalisis statistic kecelakaan dilihat dari potensi kecelakaan, lokasi rawan kecelakaan, accident rate, serta kerugian yang ditimbulkan akibat kecelakaan lalu lintas.
\end{abstract}

Kata kunci: Kecelakaan lalu lintas, Sulawesi Selatan, Transportasi

\section{PENDAHULUAN}

Perkembangan transportasi yang pesat secara tidak langsung akan memperbesar resiko tumbuhnya permasalahan lalu lintas. Kecelakaan lalu lintas menurut UU RI No. 22 tahun 2009 adalah suatu peristiwa di jalan raya tidak diduga dan tidak disengaja melibatkan kendaraan dengan atau tanpa pengguna jalan lain yang mengakibatkan korban manusia dan/atau kerugian harta benda. Kecelakaan lalu lintas umumnya terjadi karena berbagai faktor penyebab seperti pelanggaran atau tindakan tidak hatihati para pengguna (pengemudi dan pejalan kaki), kondisi jalan, kondisi kendaraan, cuaca dan pandangan yang terhalang. Pelanggaran lalu lintas yang cukup tinggi serta kepemilikan kendaraan pribadi yang semakin hari semakin meningkat, hal ini secara tidak langsung akan memicu terjadinya kecelakaan lalu lintas.

Kecelakaan lalu lintas dijalan raya merupakan penyumbang angka kematian terbesar di dunia. World Health Organization (WHO) mencatat hampir 3.400 orang meninggal di jalan dunia setiap hari. Puluhan juta orang terluka setiap tahun. Anak, pejalan kaki, pengendara sepeda dan orang tua paling rentan dari pengguna jalan. Secara umum Kepolisian Republik Indonesia (POLRI) mencatat 98.419 kecelakaan pada tahun 2017. Jumlah kecelakaan lalu lintas di Indonesia mengalami peningkatan setiap tahun. Banyaknya angka kecelakaan seiring dengan jumlah kendaraan bermotor yang terus meningkat (Annisa \& Lucia, 2016).

Pelaporan oleh polisi dan keakuratan laporan polisi akan memastikan penentuan pengelompokan penyebab terjadinya kecelakaan dan dengan demikian akan memungkinkan penyusunan daftar penyebab sebagai sesuatu yang berpengaruh pada terjadinya kecelakaan. Hal ini dilakukan dengan menyusun jumlah data kecelakaan pada lokasi tertentu dan jenis cedera kecelakaan atau sistem pembobotan (Asian 
Development Bank, 1998: 42). Untuk menganalisis setiap permasalahan yang ada, langkah pertama adalah membawa pengetahuan ke data yang ada. Penemuan pengetahuan dimulai pada lingkungan tingkat dan pengumpulan data dari sumber data. Mencermati data, tujuan dapat disesuaikan, dan berdasarkan tujuan data target dapat dipilih.

Seiring dengan bertambahnya jumlah penduduk di Provinsi Sulawesi Selatan tiap tahunnya menyebabkan kebutuhan akan transportasi juga semakin meningkat, secara tidak langsung akan memperbesar resiko tumbuhnya permasalahan transportasi. Permasalahan transportasi (Tamin, 2000) tidak hanya terbatas pada terbatasnya prasarana transportasi yang ada, namun sudah merambah kepada aspek-aspek lainnya, seperti pendapatan rendah, urbanisasi yang cepat, terbatasnya sumber daya, khususnya dana, kualitas dan kuantitas data yang berkaitan dengan transportasi, kualitas sumber daya manusia, disiplin yang rendah, dan lemahnya perencanaan dan pengendalian, sehingga aspek-aspek tersebut memperparah masalah transportasi.

Sulawesi Selatan sebagai salah satu provinsi dengan jumlah pergerakan antar wilayah yang cukup padat. Dengan intensitas pergerakan yang sibuk, tidak sedikit kecelakaan lalu lintas yang terjadi. Tulisan ini menganalisis statistic kecelakaan dilihat dari potensi kecelakaan, lokasi rawan kecelakaan, accident rate, serta kerugian yang ditimbulkan akibat kecelakaan lalu lintas.

\section{METODOLOGI PENELITIAN}

Jenis penelitian ini adalah penelitian deskriptif-evaluatif, dengan pendekatan kualitatif. Penelitian deskriptif dapat diartikan sebagai proses pemecahan masalah yang dianalisa dengan menggambarkan keadaan obyek penelitian pada saat ini berdasarkan fakta-fakta yang nampak atau kondisi eksisting (Fisu, 2016).

\section{Metode Analisis}

Accident frekuensi

Dengan metode ini dapat diketahui besarnya jumlah kecelakaan yang terjadi dalam setahun untuk setiap kilometernya, sehingga akan diperoleh ruas mana yang merupakan ruas tertinggi atau terendah tingkat kecelakaannya (blackspot). Persamaan untuk menghitung tingkat kecelakaan dengan metode frekuensi kecelakaan (Accident Frequency Method) adalah:

$$
\mathrm{AF}=\frac{A}{(L \times T)}
$$

Keterangan:

$$
\begin{array}{ll}
\mathrm{AF} & =\text { Accident Frequency (kecelakaan } / \mathrm{km} / \mathrm{th}) \\
\mathrm{A} & =\text { Jumlah Kecelakaan } \\
\mathrm{L} & =\text { Panjang Segmen } / \text { Ruas }(\mathrm{km}) \\
\mathrm{T} & =\text { Periode (tahun) } \\
\text { Tingkat } & \text { Kecelakaan }
\end{array}
$$

\section{Tingkat Kecelakaan}

Menggabungkan frekuensi kecelakaan dengan keberadaan kendaraan (yakni, volume lalu lintas) dan dinyatakan sebagai "kecelakaan per juta kendaraan untuk persimpangan" atau "kecelakaan per juta kendaraan - mil perjalanan" untuk bagian jalan raya. Tempatnya kemudian diperingkat dalam urutan tingkat kecelakaan yang menurun. Sistem jalan raya yang panjangnya 10.000 mil atau kurang dapat menggunakan metode ini. 


$$
\operatorname{Rsp}=\frac{A(1.000 .000)}{365(T V)}
$$

Dengan:

Rsp = Tingkat kecelakaan disatu titik (kecelakaan/juta kendaraan)

Rse = Tingkat kecelakaan di bagian jalan (kecelakaan/juta kendaraan-mil)

A = Jumlah kecelakaan untuk periode kajian

$\mathrm{T}=\mathrm{AADT}$ selama periode kajian (untuk persimpangan)

$\mathrm{V} \quad=$ Perjumlahan volume yang masuk untuk seluruh cabang persimpangan

$\mathrm{L} \quad=$ panjang bagian jalan (mil)

\section{HASIL DAN PEMBAHASAN}

\section{Karakteristik Pergerakan dan Guna Lahan}

Kepadatan penduduk di Provinsi Sulawesi Selatan cukup tinggi yaitu mencapai $186 \mathrm{~km}^{2}$. Kepadatan penduduk dipengaruhi oleh jumlah penduduk dan luas wilayah kabupaten/kota. Pentingnya mengetahui jumlah kepadatan penduduk agar kita dapat melihat pola potensi bangkitan dan bangkitan di Provinsi Sulawesi Selatan. Semakin tinggi kepadatan penduduk di suatu wilayah/zona, maka semakin tinggi pula potensi bangkitan dan bangkitan yang terjadi pada wilayah/zona tersebut. Selain itu, pembangunan atau pengembangan sarana transportasi juga dapat menimbulkan dampak positif terhadap suatu wilayah (Fisu. 2018), dan di sisi lain pertumbuhan aktivitas ekonomi akan mempengaruhi permintaan terhadap transportasi yang lebih banyak (Fisu. 2019). Selain itu, kegiatan pembangunan dan pengembangan infrastruktur perlu pengkajian mendalam dari berbagai sisi, termasuk aspek daya dukung lahan dan aspek tat ruang (Fisu, 2019). Kegiatan transportasi harus dilakukan secara menyeluruh dengan keterpaduan fisik antar moda berupa titik simpul pertemuan antar moda (Humang. 2016). Dari potensi bangkitan perjalanan, potensi terbesar pergerakan berasal dari wilayah dengan jumlah penduduk yang besar yakni dari wilayah Kota Makassar sebagai ibukota Provinsi dan yang kedua adalah Kabupaten Bone yang merupakan salah satu Pusat Kegiatan Wilayah di Sulawesi Selatan. Sedangkan untuk Kota Pare-Pare dan Kota Palopo meskipun memiliki jumlah penduduk yang rendah, namun sebagai Pusat Kegiatan Wilayah Sulawesi Selatan keduanya memiliki tingkat pergerakan yang cukup tinggi

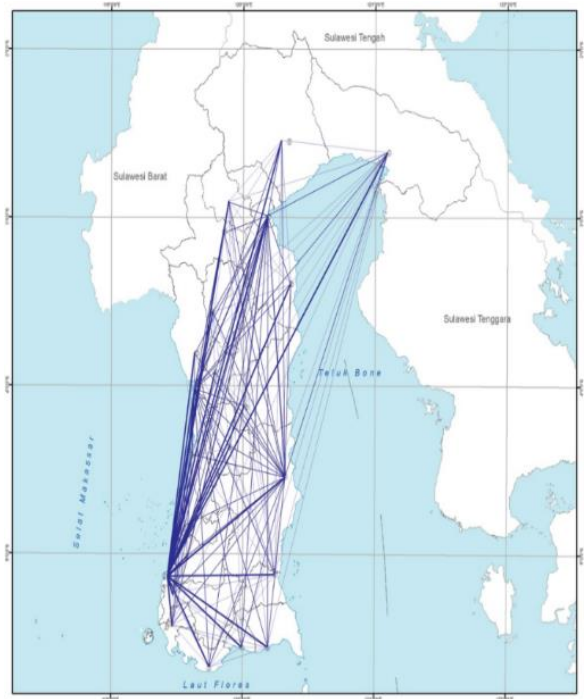

Gambar 1. Desire Line Pergerakan di Sulawesi Selatan 
Banyak faktor yang dapat mempengaruhi tingginya angka kecelakaan. Salah satu faktor yang penting adalah kondisi lalu lintas, dimana kondisi lalu lintas merupakan akumulasi interaksi dari berbagai karakteristik pengemudi, kendaraan, prasarana jalan, maupun karakteristik lingkungan (Wicaksono, Fathurochman \& Riyanto, 2014). Kecelakaan lalu lintas menjadi ekses negatif dari pemanfaatan infrastruktur jalan (Zanuardi \& Suprayitno, 2018). Perilaku lalu lintas dan tata guna lahan di Sulawesi Selatan mempengaruhi kondisi yang ada di setiap kawasan. Jaringan jalan trans Sulawesi Selatan yang banyak dilalui oleh kendaraan yang bergerak antar zona, apalagi jika jalan tersebut diselingi dengan banyaknya simpang, akan mengundang munculnya kegiatan ekonomi. Terutama apabila jika simpang yang ada dalam posisi yang saling berdekatan sehingga menghasilkan banyak blok dan kondisi jalan ada sebagian yang diperuntukkan sebagai areal parkir. Sehingga tentu saja hasilnya adalah munculnya berbagai macam kegiatan ekonomi yang menjadikan kawasan tersebut sebagai kawasan perdagangan dan jasa. Hal ini juga berkaitan dengan perilaku perjalanan dan pengendara, yang saling mempengaruhi dengan penggunaan tata ruang kawasan. Jadi fungsi kawasan, terutama kawasan perdagangan dan jasa sangat dipengaruhi oleh pola jaringan dan fungsinya, serta tata guna lahan dan peruntukannya. Povinsi Sulawesi Selatan masih didominasi oleh hutan lahan kering dan sawah. Namun apa bila dilihat lebih detil, terutama penggunaan lahan di sekitar jalan, maka terlihat bahwa terdapat konsentrasi aktifitas di sekitar jalan.

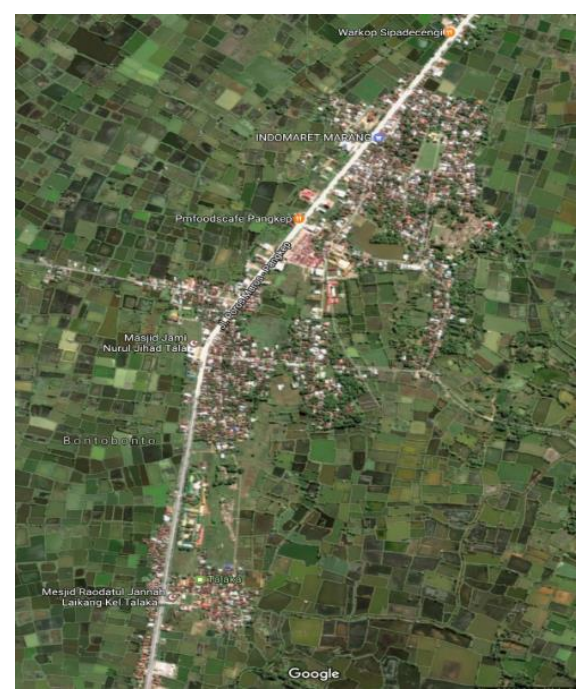

Gambar 2. Foto Udara Salah Satu Ruas Jalan Trans Sulawesi Selatan dengan Guna

Lahan Permukiman di Sekitarnya

Meskipun bukan berada di pusat-pusat kegiatan wilayah ataupun kegiatan lokal, namun pola pengembangan permukiman yang cenderung mengikuti dan mendekati jalan juga terjadi pada wilayah-wilayah lainnya. Pertumbuhan permukiman di sekitar jalan juga tentu akan dibarengi dengan aktivitas-aktivitas lain seperti sekolah, aktifitas komersil, dan lain-lain. Hal ini diakibatkan nilai ekonomis lahan-lahan di pinggir jalan lebih tinggi, dan aksesibilitas lahan di pinggir jalan lebih mudah. Namun hal ini juga dapat menjadi masalah. Jalan trans Sulawesi merupakan jalan nasional yang mengakomodasi pergerakan antar kabupaten/ kota, bahkan antar provinsi di Pulau Sulawesi. Kecepatan kendaraan yang melintasi jalan ini berpotensi membahayakan orang-orang yang beraktifitas di pinggir jalan. Sehingga perlu untuk diidentifikasi titik-titik ataupun ruas-ruas jalan yang memiliki intensitas pergerakan atau aktifitas 
yang cenderung tinggi dibandingkan dengan lokasi lain sebagai lokasi yang memiliki potensi rawan kecelakaan.

Meskipun memiliki karakteristik pesisir, Provinsi Sulawesi Selatan juga memiliki daerah-daerah di dataran tinggi seperti pegunungan dan perbukitan. Pada kegiatan kali ini, pembagian karakteristik geometric jalan secara umum dapat dibagi menjadi dua kategori, yaitu cenderung datar, berbukit/ berkontur, dan berkelok. Kondisi jalan yang berada di daerah pesisir dari Kabupaten Sinjai, Kabupaten Bulukmumba, Bantaeng, Janeponto, Takalar, Gowa, Makassar, Maros, Barru, Pare-pare dan Pinrang cenderung datar dan lurus. Sedangkan daerah-daerah yang berbukit pada poros Maros - Bone via Camba, ruas Gowa - Sinjai via Malino, rusa Enrekang - Toraja - Toraja Utara Palopo, ruas Soppeng Barru via Bulu Dua. Kondisi topografi jalan akan sangat mempengaruhi pengemudi dalam mengendarai kendaraannya. Semakin berkontur maka pengemudi diminta lebih berhati-hati dalam mengendarai kendaraannya. Termasuk pada wilayah-wilayah atau ruas-ruas yang telah di sebutkan di atas.
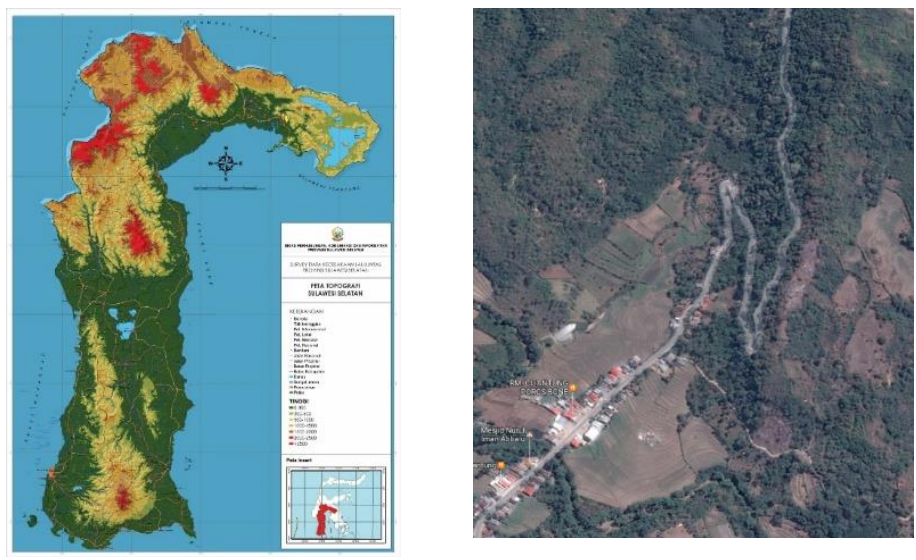

Gambar 3. Peta Kontur Sulawesi Selatan \& Foto udara ruas jalan berbukit

\section{Lokasi Rawan Kecelakaan}

Daerah rawan kecelakaan adalah daerah yang mempunyai angka kecelakaan tinggi, resiko kecelakaan tinggi dan potensi kecelakaan tinggi pada suatu ruas jalan. Daerah rawan kecelakaan (Blackspot) dapat diidentifikasi pada lokasi jalan tertentu. Daerah yang memiliki angka kecelakaan tinggi dikategorikan sebagai daerah rawan kecelakaan atau black spot karena memiliki intensitas atau frekuensi yang tinggi terjadinya kecelakaan lalu lintas. Hal ini sangat perlu diidentifikasi untuk mencari tahu apa penyebab terbesar dari tingginya intensitas dan frekuensi terjadinya kecelakaan lalu lintas pada suatu lokasi. Parameter atau indikator yang digunakan adalah jumlah kecelakaan yang diperoleh dari data Direktorat Lalu Lintas Kepolisian Daerah Provinsi Sulawesi Selatan.

Faktor penyebab kecelakaan lalu lintas antara lain adalah faktor kendaraan dan factor manusia (Azizirahman, Normelani, \& Arisanty. 2015). Manusia sebagai salah satu penyebab kecelakaan merupakan perpaduan antara kondisi fisik pengendara dan perilaku ketika berkendara. (Suraji dkk.2010). Daerah yang memiliki potensi kecelakaan tinggi sangat perlu untuk diidentifikasi. Hal ini perlu diidentifikasi untuk mengidentifikasi dan menganalisis permasalahan potensi-potensi kecelakaan tersebut dan mengurangi bahkan menghapus potensi-potensi kecelakaan tersebut. Parameter atau indicator ruas-ruas yang memiliki potensi tinggi terjadinya kecelakaan yaitu dilihat dari tata guna lahan di sekitar jalan. Semakin tinggiintensitas kegiatan di sekitar 
jalan maka semakin tinggi potensi terjadinya kecelakaan. Selain itu juga daerah-daerah yang memiliki geometric jalan yang berkontur juga menambah potensi terjadinya kecelakaan.

Selain itu, daerah yang memiliki resiko kecelakaan tinggi juga sangat penting untuk diidentifikasi untuk mengurangi resiko kecelakaan lalu lintas apabila terjadi pada suatu ruas atau titik di suatu wilayah. Parameter atau indicator yang digunakan untuk mengidentifikasi lokasi resiko kecelakaan tinggi adalah dengan mengidentifikasi lokasi-lokasi ekstem seperti jurang dan tikungan tajam.

Tabel 1. Kriteria Titik Rawan Kecelakaan/Black Spot

\begin{tabular}{|c|c|c|}
\hline No. & Kategori & Kriteria \\
\hline 1 & \multirow{3}{*}{ Titik rawan kecelakaan } & Angka kecelakaan tinggi \\
\hline 2 & & Resiko kecelakaan tinggi \\
\hline 3 & & Potensi kecelakaan tingg \\
\hline
\end{tabular}

Berdasarkan kriteria titik rawan kecelakaan di atas, dan ditunjang dengan data-data dari Ditlantas Polda Sulsel, maka dapat diidentifikasi titik-titik rawan kecelakaan lalu lintas yang dapat di lihat pada peta lokasi rawan kecelakaan lalu lintas berikut ini.

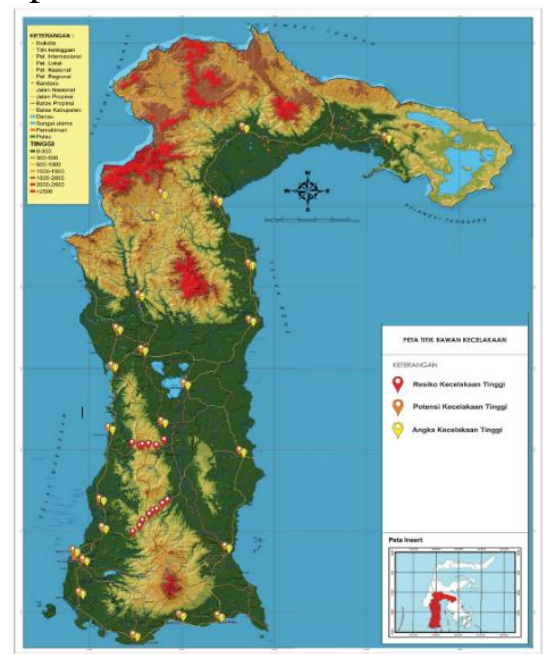

Gambar 4 Peta Titik Rawan Kecelakaan Sulawesi Selatan

\section{Accident rate}

Di negara-negara maju, suatu kebijakan, perencanaan dan program-program keselamatan jalan disusun berdasarkan sistem pangkalan data yang telah terbangun dengan baik. Namun, di negara berkembang, termasuk Indonesia, hal ini belum sepenuhnya dapat dilakukan karena tidak tersedianya data-data terkait perencanaan dan program keselamatan, data yang tersedia hanya bersifat umum dan kurang memberi informasi yang spesifik (Sugiyanto \& Santi, 2015). .Dengan menggunakan data jumlah kecelakaan dan jumlah penduduk kabupaten/kota di Provinsi Sulawesi Selatan, maka dapat dihitung angka kecelakaan berdasarkan populasi. Dari hasil analisis diketahui bahwa tingkat kecelakaan berdasarkan populasi yang paling tinggi adalah Kota Palopo. Dari 100.000 jiwa penduduk terjadi sekitar 119 kejadian kecelakaan lalu lintas. Angka kecelakaan tertinggi kedua adalah Kota Pare-pare. Dari 100.000 penduduk Kota Pare-pare, terdapat sekitar 101 - 102 kejadian kecelakaan. Jumlah terendah adalah Kabupaten Luwu Timur. Dari 100.000 jumlah penduduk di Kabupaten Luwu Timur hanya terjadi sekitar 28 kecelakaan. Makassar yang merupakan kawasan terpadat dengan jumlah kecelakaan tertinggi, tiap 100.000 
populasi penduduknya hanya terjadi 54 - 55 kejadian kecelakaan lalu lintas.Sedangkan untuk Sulawesi Selatan sendiri, dari 100.000 penduduknya, terjadi sekitar 47 kecelakaan.

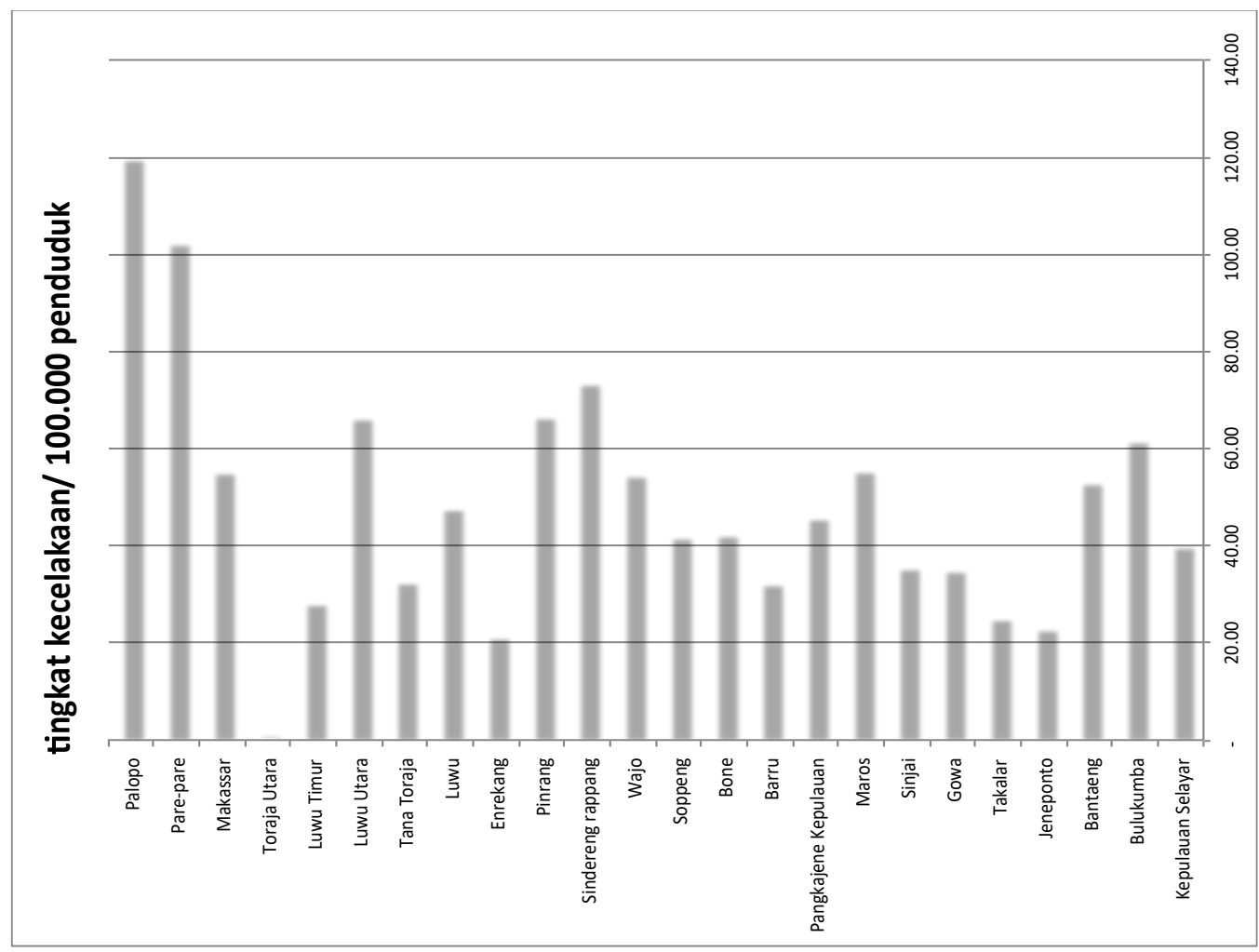

Gambar 5: Grafik Angka Kecelakaan per 100.000 Populasi Penduduk Sulawesi Selatan

Menurut Songer dalam Indriani dan Indawati (2006) menyebutkan bahwa jumlah kendaraan bermotor yang meningkat dari tahun ke tahun merupakan faktor pendukung meningkatnya jumlah kecelakaan lalu-lintas. Kepadatan lalulintas (volume kendaraan), musim (kemarau/hujan), jenis kendaraan, bermotor, waktu (gelap/terang), perilaku berkendara yang aman (safety riding), kondisi kendaraan merupakan beberapa faktor yang mempengaruhi terjadinya kecelakaan lalu-lintas. Untuk akumulasi jumlah kendaraan di Sulawesi Selatan, dikonversi menjadi satuan mobil penumpang (smp), agar memudahkan proses analisis.

Dari hasil analisis diperoleh bahwa tingkat kecelakaan berdasarkan jumlah kendaraan yang paling tinggi adalah Kabupaten Bantaeng. Dari 10.000 smp kendaraan terjadi sekitar 63 kejadian kecelakaan lalu lintas. Angka kecelakaan tertinggi kedua adalah Kabupaten Kepulauan Selayar. Dari 10.000 smp kendaraan, terdapat sekitar 62 - 63 kejadian kecelakaan lalu lintas. Jumlah terendah justru terletak di Kota Makassar. Meskipun jumlah kecelakaan di Kota Makassar terbilang tinggi, namun jumlah kendaraan di Kota Makassar sanagt tinggi. Dari 10.000 smp kendaraan di Kota Makassar, hanya terjadi sekitar 9 sampai 10 kejadian kecelakaan. .Sedangkan untuk Sulawesi Selatan sendiri, dari 10.000 smp kendaraan, terjadi sekitar 32 kejadian kecelakaan. 


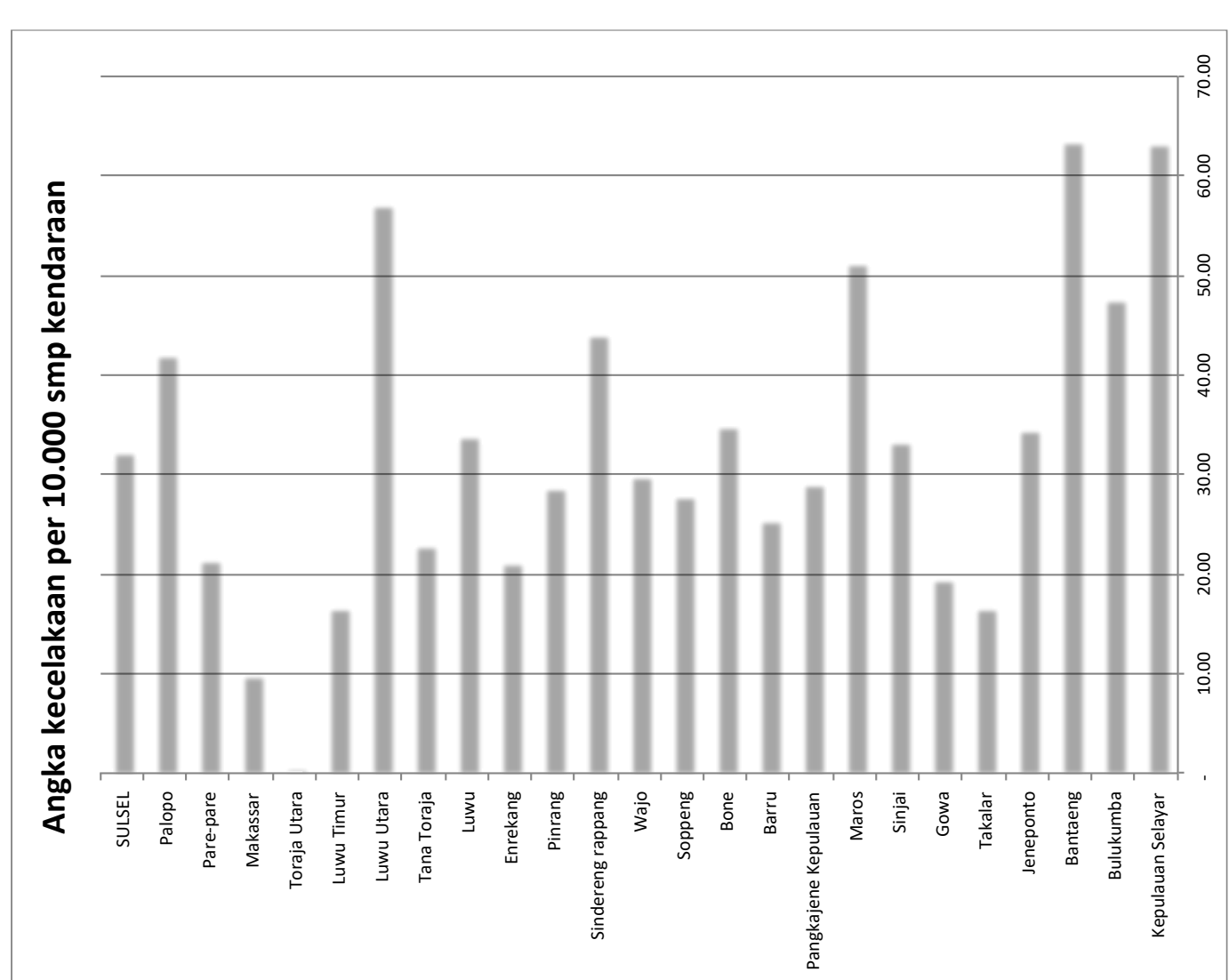

Gambar 6: Grafik Angka Kecelakaan per 10.000 smp Kendaraan Sulawesi Selatan

Angka kecelakaan berdasarkan kendaraan kilometer perjalanan dapat diartikan sebagai bahaya lalu lintas yang diekspresikan sebagai jumlah kecelakaan berdasarkan jumlah kecelakaan yang terlibat dengan memasukkan komponen volume lalu lintas harian rata-rata.. Angka vehicle boleh jadi diekspresikan dalam bagian kematian, lukaluka, atau kecelakaan total per 100 juta vehicle. Persamaan untuk menghitung angka kecelakaan berdasarkan kendaraan terlibat adalah sebagai berikut.

$R_{A I R}=\frac{\operatorname{Ran} x 100.000 .000}{V}$

Keterangan:

$R_{A I R}=$ Angka kecelakaan berdasarkan kendaraan terlibat

Ran = Jumlah kendaraan terlibat per Km per tahun

$V \quad=$ Volume lalu lintas harian rata-rata

Kendaraan yang terlibat pada sebuah kecelakaan kebanyakan lebih dari satu unit kendaraan. Namun tidak menutup kemungkinan terjadinya kecelakaan tunggal. Sehingga dipertimbangkan sekitar 35\% jumlah kecelakaan tunggal dari total jumlah kecelakaan. Sedangkan $65 \%$ sisanya diasumsikan sebagai kecelakaan yang melibatkan lebih dari satu kendaraan. Dengan menggunakan perbandingan jumlah unit kendaraan dengan satuan mobil penumpang di Sulawesi Selatan, dan proporsi jumlah kendaraan yang terlibat kecelakaan lalu lintas serta data panjang jalan di Sulawesi Selatan, maka diperoleh jumlah kendaraan terlibat per kilometer per tahun yaitu:

$$
\begin{aligned}
R_{A I R}= & \frac{R}{J_{P}} \frac{6640}{1447,51} \\
& =5,79
\end{aligned}
$$


Berdasarkan hasil perhitungan di atas, maka diketahui jumlah kendaraan terlibat per kilometer per tahun adalah 5,79. Artinya setiap $1 \mathrm{~km}$ jalan di provinsi Sulawesi Selatan terdapat 5-6 unit kendaraan yang terlibat kecelakaan dalam satu tahun.

Dengan menggunakan rumus angka kecelakaan berdasarkan kendaraan terlibat yang telah dijelaskan sebelumnya, maka diperoleh angka tingkat kecelakaan berdasarkan kendaraan yang terlibat, dan dengan menggunakan variabel lalu lintas harian rata-rata tiap kabupaten/ Kota di Sulawesi Selatan, yaitu:

$$
\begin{aligned}
R_{\text {AIR }} & =\frac{\operatorname{Ran} \times 100.000 .000}{V} \\
& =\frac{5,79 \times 100.000 .000}{122.600,38} \\
& =4.722,66
\end{aligned}
$$

\section{Kerugian Akibat Kecelakaan}

Banyaknya korban dan kerugian yang ditimbulkan, baik akibat hilangnya nyawa, maupun biaya yang diperlukan untuk pengobatan dan rehabilitasi penderita, maka kecelakaan lalu lintas termasuk dalam masalah kesehatan masyarakat dan memerlukan perhatian serius dari semua pihak yang terkait (Marsaid, Hidayat, Ahsan, 2013).

Dari data yang diperoleh dapat dilihat bahwa jumlah korban kecelakaan didominasi oleh korna luka ringan. Jumlah korna luka ringa tertinggi berada di Kota Makassar mencapai hampir 900 orang. Sedangkan jumlah korban luka ringan terendah terdapat di Kabupaten Barru dan Jeneponto yaitu masing-masing sebanyak 39 orang. Jumlah total korna luka ringan akibat kecelakaan lalu lintas di Provinsi Sulawesi Selatan sebanyak 4.509 orang.

Untuk jumlah kecelakaan luka berat tertinggi berada di Kabupaten Bone sebanyak 144 orang., dan jumlah korban kecelakaan luka berat terendah terdapat pada Kabupaten Pangkep sebanyak dua orang. Sedangkan Kota Palopo, Kabupaten Tana Toraja, dan Kabupaten Sinjai nihil korna luka berat karena kecelakaan lalu lintas. Jumlah total korban luka berat karena kecelakaan lalu lintas di Provinsi Sulawesi Selatan sebanyak 656 orang.

Sedangkan untuk korban kecelakaan lalu lintas yang meninggal dunia, yang tertinggi terdapat di Kota Makassar berjumlah 109 orang, dan terendah berada di kabupaten Kepulauan Selayar sebanyak 6 orang. Jumlah total korban meninggal dunia karena kecelakaan lalu lintas di Provinsi Sulawesi Selatan sebanyak 951 jiwa, lebih banyak dari pada jumlah korban luka berat.

Untuk kerugian materil karena kecelakaan lalu lintas paling tinggi adalah Kota Makassar, berbanding lurus dengan jumlah kecelakaan yang terjadi. Sedangkan kerugian materil tertinggi kedua adalah Kabupaten Barru, meskipun jumlah kecelakaannya tidak sebesar Kabupaten Bone, namun kerugian materil yang dialami lebih besar dalam dua tahun terakhir.

Berdasarkan data di atas, dapat diperoleh angka rata-rata jumlah kerugian materil akibat kecelakaan lalu lintas tiap kabupaten/kota di Provinsi Sulawesi Selatan. 
PENA TEKNIK: Jurnal Ilmiah Ilmu-Ilmu Teknik

Volume 4, Nomor 1, Maret 2019: 53 - 65

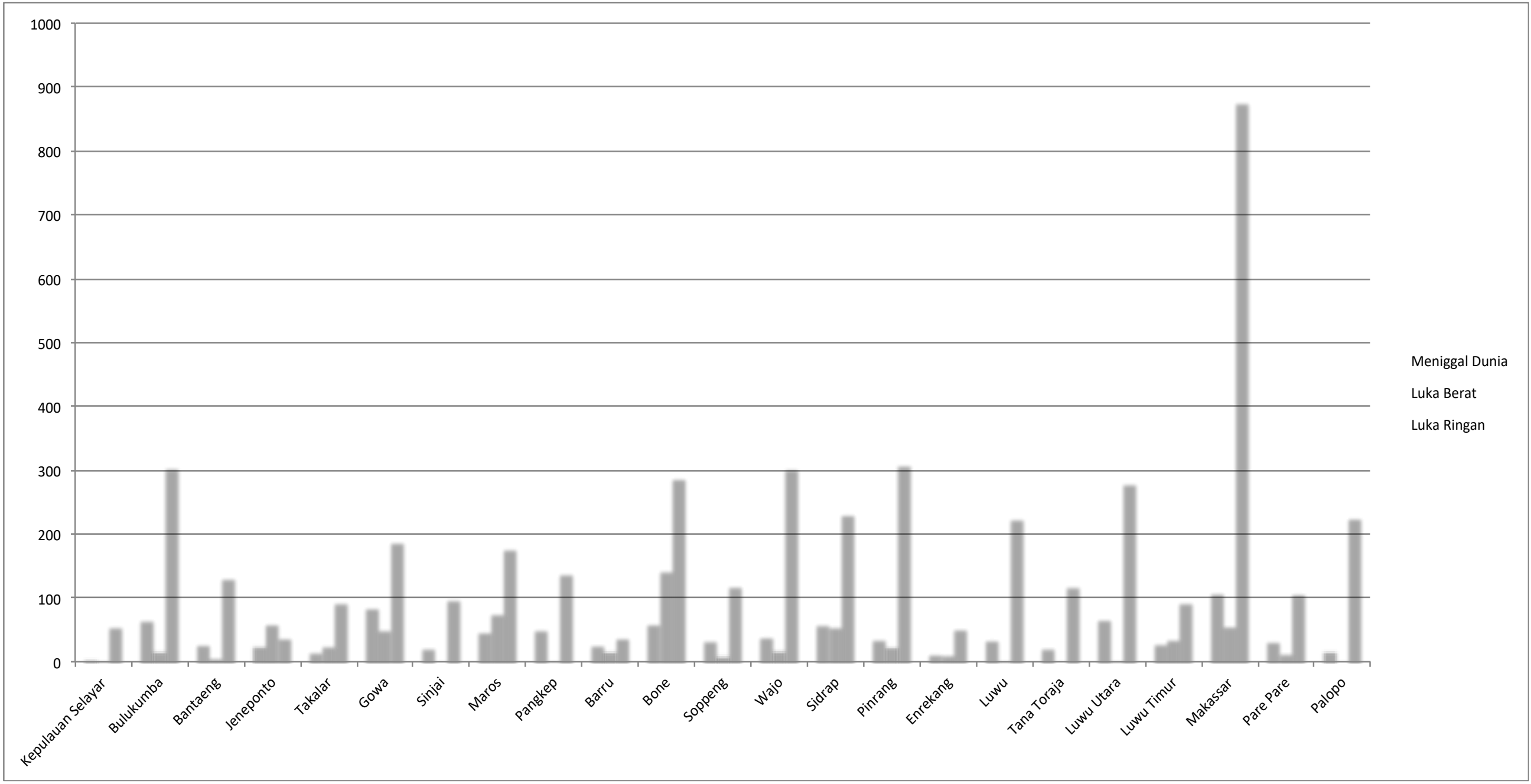

Gambar 7. Grafik Jumlah Korban Kecelakaan Lalu Lintas di Sulawesi Selatan 


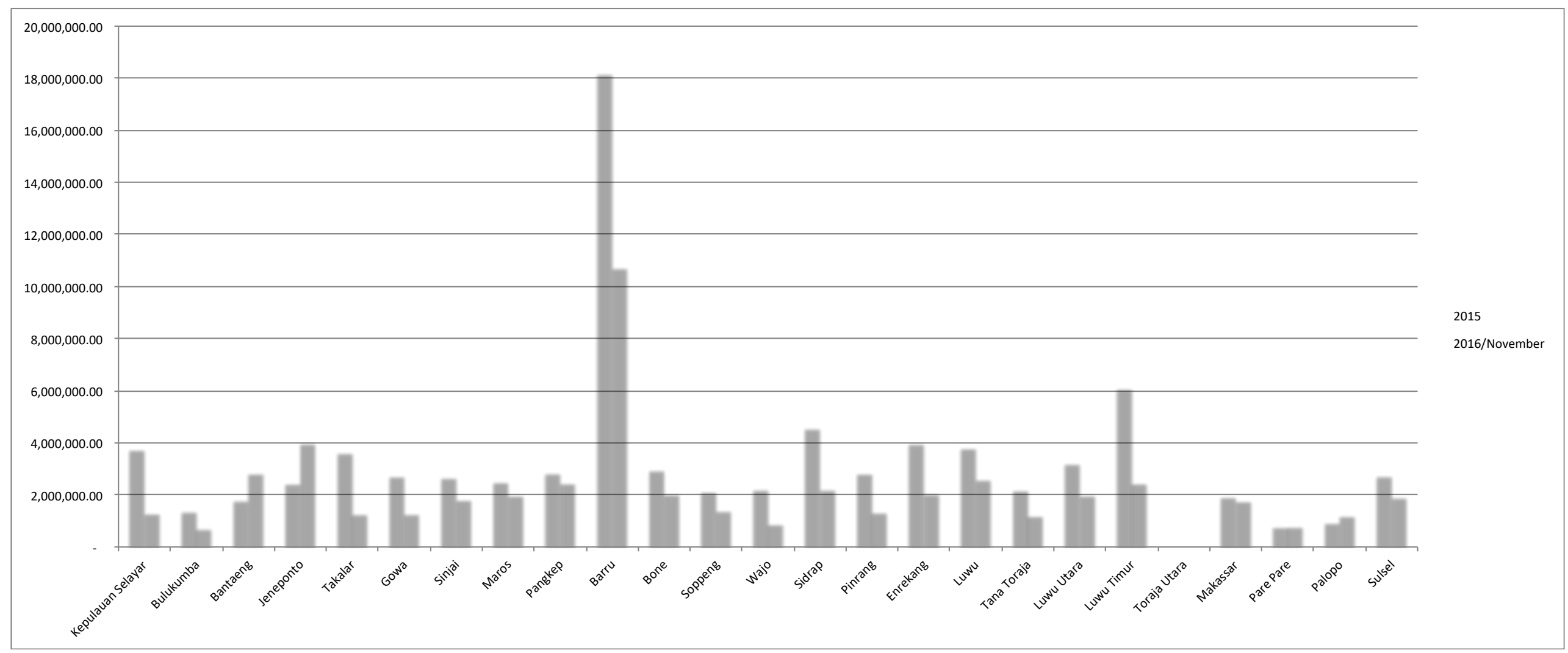

Gambar 8. Grafik Rata-rata Kerugian Materil Tiap kecelakaan di Sulawesi Selatan 


\section{KESIMPULAN}

Tingkat kecelakaan berdasarkan populasi yang paling tinggi adalah Kota Palopo. Dari 100.000 jiwa penduduk terjadi sekitar 119 kejadian kecelakaan lalu lintas. Angka kecelakaan tertinggi kedua adalah Kota Pare-pare. Dari 100.000 penduduk Kota Parepare, terdapat sekitar $101-102$ kejadian kecelakaan. Jumlah terendah adalah Kabupaten Luwu Timur. Dari 100.000 jumlah penduduk di Kabupaten Luwu Timur hanya terjadi sekitar 28 kecelakaan. Makassar yang merupakan kawasan terpadat dengan jumlah kecelakaan tertinggi, tiap 100.000 populasi penduduknya hanya terjadi 54 - 55 kejadian kecelakaan lalu lintas.Sedangkan untuk Sulawesi Selatan sendiri, dari 100.000 penduduknya, terjadi sekitar 47 kecelakaan.

Tingkat kecelakaan berdasarkan jumlah kendaraan yang paling tinggi adalah Kabupaten Bantaeng. Dari 10.000 smp kendaraan terjadi sekitar 63 kejadian kecelakaan lalu lintas. Angka kecelakaan tertinggi kedua adalah Kabupaten Kepulauan Selayar. Dari 10.000 smp kendaraan, terdapat sekitar 62 - 63 kejadian kecelakaan lalu lintas. Jumlah terendah justru terletak di Kota Makassar. Meskipun jumlah kecelakaan di Kota Makassar terbilang tinggi, namun jumlah kendaraan di Kota Makassar sanagt tinggi. Dari $10.000 \mathrm{smp}$ kendaraan di Kota Makassar, hanya terjadi sekitar 9 sampai 10 kejadian kecelakaan. .Sedangkan untuk Sulawesi Selatan sendiri, dari $10.000 \mathrm{smp}$ kendaraan, terjadi sekitar 32 kejadian kecelakaan.

Untuk jumlah kecelakaan luka berat tertinggi berada di Kabupaten Bone sebanyak 144 orang., dan jumlah korban kecelakaan luka berat terendah terdapat pada Kabupaten Pangkep sebanyak dua orang. Sedangkan Kota Palopo, Kabupaten Tana Toraja, dan Kabupaten Sinjai nihil korna luka berat karena kecelakaan lalu lintas. Jumlah total korban luka berat karena kecelakaan lalu lintas di Provinsi Sulawesi Selatan sebanyak 656 orang. Sedangkan untuk korban kecelakaan lalu lintas yang meninggal dunia, yang tertinggi terdapat di Kota Makassar berjumlah 109 orang, dan terendah berada di kabupaten Kepulauan Selayar sebanyak 6 orang. Jumlah total korban meninggal dunia karena kecelakaan lalu lintas di Provinsi Sulawesi Selatan sebanyak 951 jiwa, lebih banyak dari pada jumlah korban luka berat. Untuk kerugian materil karena kecelakaan lalu lintas paling tinggi adalah Kota Makassar, berbanding lurus dengan jumlah kecelakaan yang terjadi. Sedangkan kerugian materil tertinggi kedua adalah Kabupaten Barru, meskipun jumlah kecelakaannya tidak sebesar Kabupaten Bone, namun kerugian materil yang dialami lebih besar dalam dua tahun terakhir.

\section{DAFTAR PUSTAKA}

Annisa H. \& Lucia Y.H. (2016). Analisis Resiko Kecelakaan Lalu Lintas Berdasar Pengetahuan, Penggunaan Jalur, dan Kecepatan Berkendara. Jurnal Berkala Epidemologi Vol. 04 No. 02 Mei 2016: 275-287

Azizirahman M, E. Normelani \& D Arisanty. (2015). Faktor Penyebab Terjadinya Kecelakaan Lalu Lintas pada Daerah Rawan Kecelakaan di Kecamatan Banjarmasin Tengah Kota Banjarmasin. Jurnal Pendidikan Geografi Vol.02 No.03 Mei 2015 20-37

A.Suraji dkk. (2010). Indikator Faktor Manusia Terhadap Kecelakaan Sepeda Motor. Jurnal Transportasi Vol.10 No.02 Agustus 2010 125-134

Fisu AA. (2018). Analisis Kebutuhan Fasilitas Sisi Laut Pelabuhan Terminal Khusus PLTGU Lombok. Jurnal Pena Teknik Vol.02 No.01 2018

Fisu AA. (2018). Analisis Lokasi Pada Perencanaan Terminal Topoyo, Mamuju Tengah. Jurnal Pena Teknik Vol.02 No.01 2018 
Fisu AA. (2016). Potensi Demand pengembangan Kanal Jongaya \& Panampu Sebagai Moda Transportasi Kota Makassar. Jurnal JMTranslog Trisakti Vol 03 no 03, Jakarta.

Fisu AA. (2016). Analisis dan Konsep Perencanaan Kawasan Pelabuhan Kota Penajam sebagai Pintu Gerbang kab. Penajam Paser Utara, Kalimantan Timur. Jurnal Pena Teknik Vol.01 No.02 September 2016. 125-136.

Fisu AA. (2019). Analisis Kelayakan Ekonomi \& Finansial pada Masterplan Kawasan Industri Perikanan Kota Tarakan. https://doi.org/10.31227/osf.io/96yzu

Humang Windra Priatna \& Zulfadly. (2016). Analisis Keterpaduan Moda Transportasi Angkutan Penyeberangan Dengan Jalan Raya di Pelabuhan Bajoe Kab. Bone. Jurnal Pena Teknik Universitas Andi Djemma, Palopo.

Marsaid, M. Hidayat, Ahsan. (2013). Faktor Yang Berhubungan dengan Kejadian Kecelakaan Lalu Lintas Pada Pengendara Sepeda motor di Wilayah Polres Kabupaten Malang. Jurnal Ilmu Keperawatan Vol.01 No.02 November 2013 98-112

Sugiyanto G \& M.Y. Santi. (2015). Karakteristik Kecelakaan lalu Lintas dan Pendidikan Keselamatan Berlalulintas Sejak Usia Dini Studi Kasus di Kabupaten Purbalingga. Jurnal Ilmiah Semesta Teknika Vol.18 No.01 Mei 2015 65-75

Tamin, Ofyar Z. (2000). Perencanaan dan Pemodelan Transportasi. Bandung: Penerbit ITB

Wicaksono D, Fathurochman R.A, Riyanto B. (2014). Analisis Kecelakaan lalu Lintas Studi Kasus Jalan Raya Ungaran-Bawen. Jurnal karya Teknik Sipil Vol.03 No.012014 203-213.

Zanuardi A, Suprayitno H. (2018). Analisa Karakteristik Kecelakaan lalu Lintas di Jalan Ahmad Yani Surabaya melalui Pendekatan Knowledge Discovery in Database. Jurnal Manajemen Aset Infrastruktur \& Fasilitas Vol.02 No.01 Maret 2018 45-55 
PENA TEKNIK: Jurnal Ilmiah Ilmu-Ilmu Teknik

Volume 4, Nomor 1, Maret 2019: 53 - 65

Halaman ini sengaja dikosongkan 